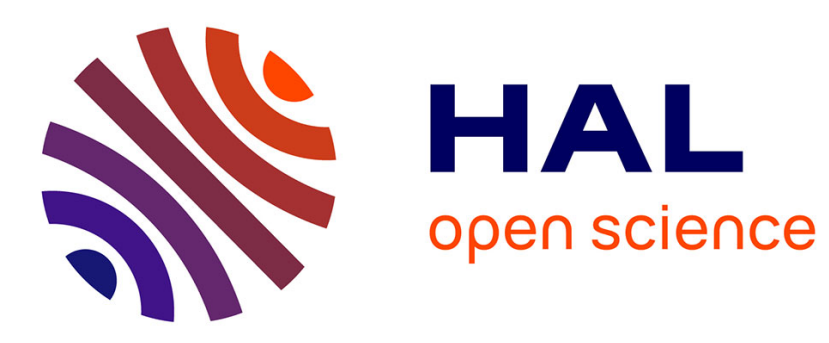

\title{
Teaching technical communication in France: Challenges and prospects
}

\author{
Dacia Dressen-Hammouda
}

\section{To cite this version:}

Dacia Dressen-Hammouda. Teaching technical communication in France: Challenges and prospects. Barry Thatcher and Kirk St Amant. Teaching Intercultural Rhetoric and Technical Communication: Theories, Curriculum, Pedagogies, and Practices, Baywood, pp.155-172, 2011, Technical Communication Series, 978-0895033772. hal-01011844

\author{
HAL Id: hal-01011844 \\ https://hal.uca.fr/hal-01011844
}

Submitted on 24 Jun 2014

HAL is a multi-disciplinary open access archive for the deposit and dissemination of scientific research documents, whether they are published or not. The documents may come from teaching and research institutions in France or abroad, or from public or private research centers.
L'archive ouverte pluridisciplinaire HAL, est destinée au dépôt et à la diffusion de documents scientifiques de niveau recherche, publiés ou non, émanant des établissements d'enseignement et de recherche français ou étrangers, des laboratoires publics ou privés. 
(2011). In B. Thatcher et K. St. Amant (eds),

Teaching Intercultural Rhetoric and Technical Communication:

Theories, Curriculum, Pedagogies, and Practices. Amityville, NY: Baywood, 155-172.

\title{
Teaching technical communication in France: Challenges and prospects
}

\section{Dacia Dressen-Hammouda}

\author{
Faculté des Langues Appliquées, Commerce, Communication \\ Université Blaise Pascal \\ Clermont-Ferrand, France
}

The importance of teaching written communication is a well-established tradition in both the U.S. and Canada, in parts of South America, as well as throughout northern Europe, including Germany, the Netherlands, Denmark, Scandinavia and Great Britain. However, while writing instruction in France is heavily emphasized in primary and secondary school education, it has until recently received only very limited attention at the post-secondary (or university and college) level. This situation, of course, has important consequences for potential French degree programs in technical communication since written communication skills are among the most essential for entry into the professional community.

This chapter describes the ongoing implementation of a two-year Masters degree program in intercultural technical communication at a mid-sized university in central France (Université Blaise Pascal, Clermont 2).

${ }^{1}$ The chapter will begin by describing the background context for the curriculum's design, including writing instruction practices at the post-secondary level and a recent reform that allows French universities to begin aligning technical communication programs more closely on North American and northern European practices. After providing a broad overview of the proposed degree program, the chapter will then conclude by briefly discussing implications for developing a curriculum that both raises intercultural awareness and develops necessary written communication skills in French university students.

\section{Background context for curriculum design}

The proposed two-year Masters course in intercultural technical communication discussed in this chapter is currently under review by the French Ministry of Education. As with all French university programs, the centralized government retains the final decision on which programs will be accredited, and which will not. What this implies is that any university program, because it is largely funded by the French government, reflects the country's current geopolitical considerations to at least some extent. The following sections of this chapter will describe this educational context, by viewing reasons why training for technical communicators in France has traditionally emphasized instruction in translation rather than in written communication. It will also provide a brief overview of the types of programs which to date have trained technical writers in France. Such an approach is meant to familiarize the reader with the nature of training in intercultural technical communication in one of the European Union's founding member states.

In effect, what is called 'technical writing' in France has long been taught through translation. The university programs that train students to work as technical writers are housed in Applied Foreign Languages for Business and Technology, or 'L.E.A.' ('Langues Etrangères Appliquées') programs. Historically, such programs specialize not in communication strategies, but in translation techniques ('thème' and 'version'). As a result of the consistent emphasis placed on translation, at both the Bachelors and the Masters level, considerably less attention has been paid to teaching students how to actually write the technical and professional documents they will need to produce in the workplace, whether in French or 
other languages.

While France's geopolitical context explains the heavy emphasis its institutions of higher education place on translation, the preference for translation training also reflects current practices in writing instruction. Notably, university students are expected to have learned the 'important' written genres during their secondary school education and to simply be able to adapt their writing skills once they come to the university (Donahue 2000). As a result, explicit writing instruction is largely absent from the university level in France. Thus, students who train to become future technical communicators often lack experience in writing because they receive little, if any, instruction in writing non-school (i.e., university and workplace) genres at the university level.

\section{The French context for post-secondary writing instruction}

The specific context for writing instruction in France thus carries particular implications for designing degree programs in technical communication, because French students are potentially under-prepared for a career in technical communication.

They do not, however, start out that way. In fact, priority is given to writing instruction throughout the primary and secondary school curricula (Donahue, 2000; 2004). At school, writing is integrated into a whole discoursal approach where children are taught to be aware of language and to use it as a tool in their move toward literacy. This French tradition of "discourse-awareness-rich" (Donahue, 2004, p. 68) teaching begins early in elementary-school education, where a writing in the disciplines (WiD) approach underlies the entire design of the curriculum. The WiD emphasis continues throughout secondary school, where writing continues to be essential in every discipline (Donahue, 2004, p. 65). Indeed, primary and secondary students in France have been found to write as much, if not more than, their school-aged American counterparts (Donahue, 2000).

Explanations for French university students' under-preparedness for writing are thus to be found elsewhere. One first explanation can be found in the types of writing instruction students do receive before coming to the university. In effect, writing instruction at the secondary level is geared primarily toward helping students pass the exit exam at the end of high school, called the Baccalauréat (commonly referred to as the 'Bac'). This institutional need pushes secondary school educators to teach students the types of genres they must master in order to pass the exit exam. ${ }^{2}$ Moreover, this educational objective particularly prepares students for one, specific type of university writing: end-of-the-semester exam writing, which is also the primary means of evaluation at the university. It is noteworthy that in France such exams are not tied to funding for education, but exist exclusively as a mechanism for evaluating students' performance in a course. Furthermore, given the 'massification' of French higher education since the 1980's (Burgel 2006) and explosion in the number of students coming to the university, such end-of-the-semester exams have become the primary means for evaluation at the university, where individual research and topic papers have become rare (Donahue 2004).

Another explanation for students' lack of writing experience at the undergraduate level is further tied to the massification of French higher education, and the conditions it has created for learning. While some undergraduate degree courses do offer writing classes, called 'techniques d'expression', the results can be quite variable. In effect, during the first two years of undergraduate studies in France, class sizes often range upwards to between 150 to 200 students. Such conditions make it nearly impossible to engage in 'process writing' or to work on controlling the effects of audience because it is not feasible to provide individual feedback to each student over the course of the semester. As a result, a single writing course is often taught as a large lecture class and students are invited to work on writing assignments together. Such conditions encourage learning to write as the mastery of stable forms, rather than of the dynamic, rhetorical actions (Miller, 1984) which need to be adapted to the imperatives of each writing situation.

To a certain extent, the lack of emphasis placed on audience-centered writing is also reflected in 
current French writing research, which tends to focus much more closely on school writing than on university writing. In effect, the field of rhetoric and composition theory or its equivalent, grounded in post-secondary issues of writing theory and pedagogy, is more or less non-existent at the French university. In addition, the study of rhetoric, in French called 'la stylistique', is limited to literary courses of study.

Instead, current French writing research reflects the priority placed on teaching writing at the primary and secondary school levels (Donahue, 2000; 2004). To better understand how younger writers become literate, writing researchers have focused on such issues as how:

- writing functions as a specific psychological activity (Fayol, 1995; 1996; 1999; 2004; Piolat \& Pélissier, 1998; Piolat, 2004);

- children become literate (Astolfi, 1993; Garcia-Debanc, 1993; Bauthier, 1995; Reuter, 1996; Altet, 1997; Plane, 2003);

- best to classify and interpret text types, considered to be stable forms (Haas \& Lorrot, 1987; Adam, 1992); or

- the relationship between language and power is related to success at school (Charlot et al., 1992; Lahire, 1993; Thin, 1998).

As can be surmised from this brief but non-exhaustive list, writing research in France has focused more on the process of literacy acquisition than on describing writing situations and their audience-related concerns.

While another trend in French writing research, from the English for Specific Purposes (ESP) tradition, does more closely address the concerns of audience, it is only a secondary concern in this research tradition. Here, French university LSP (Languages for Specific Purposes) and ESP teachers and researchers are concerned with the genre-based instruction of specialized discourses to students throughout various disciplines. This trend is represented by two French associations, APLIUT ('Association des professeurs de langues des instituts universitaires technologiques') and GERAS ('Groupe d'études et de recherche en anglais de spécialité'), whose purpose is to contribute to the development of LSP research and teaching in France. While the primary emphasis of research in this domain centers on the teaching of specialized languages in the disciplines, a fair number of these researchers have also worked toward the promotion of writing research and instruction at the postsecondary level in France. ${ }^{3}$ It is within this venue that research and teaching practices in France have at times most closely resembled the rhetorically-centered concerns of technical communication as it is practiced in Anglo-Saxon and northern European countries.

Given the general lack of emphasis placed on writing instruction in the French university curriculum, most students thus gain little experience in writing audience-centered business and professional genres at the undergraduate and graduate levels. The extent to which this may also be true of primary and secondary education is currently the subject of an ongoing investigation. What is clear, however, is that students are largely expected to carry over to the university the writing skills and practices they learned in school (e.g., end-of-the-semester exam writing). These skills are also expected to be carried over to the workplace, despite the difficulties inherent in applying school writing to other types of writing (Beaufort 1999).

This observation is confirmed by a survey made of ten existing degree programs in technical translation and writing in France, all but one of which are housed in L.E.A. departments. All such Masters-level programs currently known in France were included in the survey. If the university also offered Bachelors-level programs, these, too, were included in the survey. As can be seen in Table 1, the number of hours spent on writing instruction is significantly less than that spent on translation. 
Table 1. French universities with technical writing programs at the undergraduate and graduate levels (as of June 2006).

\begin{tabular}{|c|c|c|}
\hline Name of university & Masters level & Bachelors ('Licence') level \\
\hline $\begin{array}{l}\text { Université de Bretagne } \\
\text { Occidentale }\end{array}$ & $\begin{array}{l}\text { Master L.E.A.: Rédacteur - Traducteur } \\
\text { (given over } 1 \text { year) } \\
\text { Translation courses: } 222 \text { hours } \\
\text { Writing courses: } \mathbf{3 0} \text { hours } \\
\text { Content: unknown }\end{array}$ & $\begin{array}{l}\text { Licence L.E.A.: Langues Etrangères } \\
\text { Appliquées (given over } 4 \text { years) } \\
\text { Translation courses: } 299 \text { hours } \\
\text { Writing courses: } \mathbf{1 6 5} \text { hours } \\
\text { Content: basic writing skills in French, } \\
\text { media writing, business writing in } \\
\text { English, German/Spanish, writing } \\
\text { longer documents }\end{array}$ \\
\hline $\begin{array}{l}\text { Université Blaise Pascal } \\
\text { (Clermont 2) }\end{array}$ & $\begin{array}{l}\text { Master L.E.A.: "Production de } \\
\text { Documentation Normalisée" (given } \\
\text { over } 1 \text { year) } \\
\text { Translation courses: N/A } \\
\text { Writing courses: } 140 \text { hours } \\
\text { Content (English only): Technical } \\
\text { description, technical instructions, } \\
\text { warnings, user manuals, online } \\
\text { instructions, web writing, visual } \\
\text { communication, controlled English }\end{array}$ & $\begin{array}{l}\text { Licence L.E.A.: Langues Etrangères } \\
\text { Appliquées (given over } 4 \text { years) } \\
\text { Translation courses: } \mathbf{1 9 2} \text { hours } \\
\text { Writing courses: } \mathbf{1 2 8} \text { hours } \\
\text { Content: (44 hours of Techniques } \\
\text { d'expression); } 86 \text { hours in English: } \\
\text { reports, summaries, syntheses, process } \\
\text { descriptions, technical instructions and } \\
\text { descriptions }\end{array}$ \\
\hline Université de Paris 7 (Jussieu) & $\begin{array}{l}\text { Master L.E.A. (over } 2 \text { years) } \\
\text { (1) "Industrie des Langues et } \\
\text { Traduction Spécialisée" } \\
\text { Translation courses: } \mathbf{3 8 0} \text { hours } \\
\text { Writing courses: N/A } \\
\text { Content: N/A } \\
\text { (2) "Conception de Documentation } \\
\text { Multilingue et Multimédia" } \\
\text { Translation courses: } 122 \text { hours } \\
\text { Writing courses: } \mathbf{1 7 0} \text { hours } \\
\text { Content: Principles of writing, benefits } \\
\text { writing, technical writing }\end{array}$ & $\begin{array}{l}\text { Licence L.E.A.: "Industrie des } \\
\text { Langues et Traduction Spécialisée" } \\
\text { (over } 3 \text { years) } \\
\text { Translation courses: } 200 \text { hours } \\
\text { Writing courses: } 60 \text { hours } \\
\text { Content: Report writing, synthesis, } \\
\text { abstracts, summaries }\end{array}$ \\
\hline Université de Rennes 2 & $\begin{array}{l}\text { Master L.E.A.: "Traduction et } \\
\text { Communication Multilingue" (over } 1 \\
\text { year) } \\
\text { Translation courses: } \mathbf{2 4 5} \text { hours } \\
\text { Writing courses: } 80 \text { hours } \\
\text { Content: User manuals, online help } \\
\text { guides }\end{array}$ & $\begin{array}{l}\text { Licence L.E.A.: "Traduction et } \\
\text { Communication Multilingue" (over } 3 \\
\text { years) } \\
\text { Translation courses: } 220 \text { hours } \\
\text { Writing courses: 80 hours } \\
\text { Content: Français Rédaction générale } \\
\text { (S5), Français Rédaction et relecture } \\
\text { (S6) }\end{array}$ \\
\hline Université de Paris 12 & & $\begin{array}{l}\text { Licence L.E.A.: "Ecrits spécialisés" } \\
\text { (open to third-year Bachelors students } \\
\text { only) } \\
\text { Translation courses: N/A } \\
\text { Writing courses: } \mathbf{8 8} \text { hours } \\
\text { Content: reports, synthesis, technical } \\
\text { and professional genres }\end{array}$ \\
\hline $\begin{array}{l}\text { Université du Littoral } \\
\text { Côte d'Opale }\end{array}$ & $\begin{array}{l}\text { Master L.E.A.: "Langues et } \\
\text { Technologies" (over } 1 \text { year) } \\
\text { Translation courses: } 220 \text { hours } \\
\text { Writing courses: } 36 \text { hours } \\
\text { Content: unknown }\end{array}$ & $\begin{array}{l}\text { Licence L.E.A.: Langues Etrangères } \\
\text { Appliquées (over } 3 \text { years) } \\
\text { Translation courses: } \mathbf{2 8 8} \text { hours } \\
\text { Writing courses: } \mathbf{5 0} \text { hours } \\
\text { Content: unknown }\end{array}$ \\
\hline
\end{tabular}




\begin{tabular}{|c|c|c|}
\hline Université de Lille & $\begin{array}{l}\text { Master L.E.A.: "Traduction } \\
\text { Spécialisée Multilingue" (1 year) } \\
\text { Translation courses: } 200 \text { hours } \\
\text { Writing courses: } \mathbf{1 0} \text { hours } \\
\text { Content: unknown }\end{array}$ & $\begin{array}{l}\text { Licence L.E.A.: Langues Etrangères } \\
\text { Appliquées (over } 3 \text { years) } \\
\text { Translation courses: } 140 \text { hours } \\
\text { Writing courses: } \mathbf{5 0} \text { hours } \\
\text { Content: Report writing (French, } \\
\text { English, and } 1 \text { other language) and } \\
\text { 'Techniques d'expression' }\end{array}$ \\
\hline $\begin{array}{l}\text { Université de } \\
\text { Bretagne Sud }\end{array}$ & $\begin{array}{l}\text { Master L.E.A.: "Documents et } \\
\text { Technologies de l'Information et de la } \\
\text { Communication } \\
\text { No information available on the } \\
\text { university website }\end{array}$ & $\begin{array}{l}\text { Licence L.E.A.: "Traduction - } \\
\text { Rédaction" (over } 3 \text { years) } \\
\text { Translation courses: } \mathbf{1 6 0} \text { hours } \\
\text { Writing courses: } \mathbf{4 0} \text { hours } \\
\text { Content: unknown (3rd year only) }\end{array}$ \\
\hline $\begin{array}{l}\text { Université Jean Monnet (Saint- } \\
\text { Etienne) }\end{array}$ & $\begin{array}{l}\text { Master L.E.A.: "Traduction de } \\
\text { Produits de Communication Multi- } \\
\text { Supports" (over } 1 \text { year) } \\
\text { Translation courses: } 260 \text { hours } \\
\text { Writing courses: } 10 \text { hours } \\
\text { Content: unknown }\end{array}$ & $\begin{array}{l}\text { Licence L.E.A.: Langues Etrangères } \\
\text { Appliquées au Commerce } \\
\text { International (over } 4 \text { years) } \\
\text { No information available on the } \\
\text { university website }\end{array}$ \\
\hline $\begin{array}{l}\text { Université Technologie } \\
\text { Compiègne (UTC) }\end{array}$ & $\begin{array}{l}\text { DICIT: Concepteur - rédacteur de la } \\
\text { documentation technique } \\
\text { No information available on the } \\
\text { university website }\end{array}$ & \\
\hline
\end{tabular}

As can be observed in Table 1, most L.E.A. programs that prepare students to work as technical writers prefer translation-intensive training over writing-intensive training. In effect, students receive only around 40 to 80 hours of writing instruction over the entire course of a four-year Bachelors degree (i.e., between 0.6 and 1.3 hours of writing instruction per week). One can compare these numbers to the number of hours spent on translation training: most degree programs offer around 200 hours of translation in two languages over four years (or roughly 9 hours of translation studies per week). Two exceptions to this observation are found at the Université de Bretagne Occidentale, which offers a writing- and translation-rich Bachelors program, and Université Blaise Pascal. These Bachelors programs offer 165 and 128 hours of writing instruction, respectively (or on average, around 2.8 and 2.1 hours per week, respectively).

The emphasis on writing instruction in these two programs, however, does not carry over equally at the Master's level. While the Master's program at Université Blaise Pascal currently offers 140 hours of writing instruction over one year (6.4 hours per week), the Université de Bretagne Occidentale offers only 30 (1.4 hours per week). Also, while one of the Masters offered at Université de Paris 7 (CDMM) offers 170 hours of writing instruction, once again, this teaching is distributed over a two-year period; the actual annual teaching load ends up to be around 85 hours ( 3.8 hours per week). Rennes 2 shows similar results, with 80 hours at the Masters level (3.6 hours per week). A preliminary observation to be drawn from the data in Table 1 is therefore that written communication is typically not considered a central part of the training for future technical writers in France.

To a certain extent, the preference for translation training reflects L.E.A. programs' status in a country whose geopolitical context requires translation both into and out of French. Indeed, L.E.A. programs have long been at the forefront of translation training in France. Historically called a "bilingual bachelor's degree" ('licence bilingue', Gallet-Blanchard \& Peyronel, 2006), the purpose of an L.E.A. program is to prepare students to work in companies by giving them a solid foundation in intercultural considerations and at least two foreign languages (English plus one other language), while teaching them about the business environment they will work in (law, economics, management, marketing, etc.).

In this regard, L.E.A.'s traditional emphasis on translation creates a situation in which training for 
future technical communicators is already inherently intercultural and international in scope. Despite the potential advantage this training may offer future professionals for integrating an increasingly globalized work environment, however, French students tend to be weaker in writing tasks and the pragmatics of writing than they should, simply because they have had less experience in recreating the real language tasks that would prepare them for communicating in the workplace. ${ }^{4}$

\section{Impetus for intercultural technical communication in France}

Despite these challenges, this is an exciting time for intercultural technical communication educators in France. Most importantly, the strategic importance of having well-trained technical communicators is increasingly recognized by both multinationals and small and medium-sized enterprises (SME's) throughout France and the E.U. This, in turn, provides impetus within European and national institutions to support writing instruction and programs in technical communication. For example, a recent survey of SME's across Europe (ELAN, 2006), commissioned by the Directorate General for Education and Culture of the European Commission, ${ }^{5}$ found that over the preceding ten-year period European SME's had undergone a significant loss in business as a result of workers' poor intercultural communication skills. Based on the respondents' answers, the study estimated that at least 945,000 European SME's had been losing trade for this reason. Because strong intercultural and language training was viewed by the study authors as key for stimulating the European economy, they recommended that the educational systems and governments of member states invest more to develop adequate, government-led language policies, namely through university-based exchange, or 'Erasmus', programs (p. 40).

Of course, a greater investment in language development and the fostering of intercultural awareness are reflected in the various reforms recently implemented across the university systems of the E.U. In June 1999, for example, 29 European Ministers signed the Bologna Declaration, ${ }^{6}$ which stated that in order for Higher Education in Europe to prepare European university students to be interculturallysensitive multilingual citizens, better able to compete internationally, member states' higher education systems needed to facilitate university exchanges (Erasmus and Socrates programs) by realigning themselves upon a single model: L-M-D. The so-called 'LMD reform' sought to harmonize university structures across the E.U. by imposing a 3-year Bachelors degree (L), a two-year Masters degree (M) and a three-year Doctoral degree (D). Such reforms are key for the development of intercultural technical communication education in France because they encourage L.E.A. programs to maintain high standards in their existing intercultural and language training, while providing increased curricular opportunities for writing support.

In effect, the LMD reform has provided important opportunities for writing support at the university level in France. Within the new curricular structure resulting from the reform, the French government has increased its funding of English-language and writing instruction to first-year students ('EEO' modules, or 'expression écrite et orale'). It has further proposed funding for projects targeting intervention and support for first-year university students, including writing support in general. As a reflection of this change, a government-funded project is currently underway to study university student writing at three universities in four disciplines (C. Donahue, personal communication, November 2006). The project builds on an extensive body of literature about the specific obstacles students at French universities face with reading and using sources, placing themselves in the academic conversation, learning new genres, and other relevant writing issues. Yet another university (Université de Paris 3) has begun to test all incoming students and offer writing courses to those who need them. ${ }^{7}$

The LMD reform has also created a window of opportunity for increased writing support in the new intercultural technical communication program to be presented in the following section. As a result of the reform, which extends Masters-level study from one year to two, French programs in technical communication will have more room to develop writing-intensive modules. As of the fall of 2008, however, only two Masters programs intend to offer comprehensive, two-year training programs in 
intercultural technical communication, including intensive writing instruction (Université Paris 7 and Université Blaise Pascal). In essence, then, the challenge for intercultural technical communication training in France is not to make programs in technical communication more 'intercultural', for this quality has long existed due to France's geopolitical context and the influence this has had on national education policies (e.g., L.E.A. programs). Rather, the challenge today is to sufficiently prepare French students for a career in which written communication skills are central, in French, English and other languages.

The teaching of technical communication in France thus finds itself at a crossroads, although for different reasons than in North America. Clearly, being a well-trained technical communicator in France today implies having extensive knowledge about intercultural communication. Given France's current geopolitical and commercial context within Europe, technical communicators working in France for French companies or multinationals must necessarily possess the ability to localize and translate information effectively to a variety of audiences of differing national origins. At the same time, however, given the long-term absence of explicit writing instruction in post-secondary education in France, special emphasis still needs to be placed on teaching students the value - and to some extent, the basics - of written communication skills, in English, French, and other languages.

\section{A technical communication Masters program at Université Blaise Pascal}

The two-year Masters degree in intercultural technical communication described in the following section will replace a one-year program already in place at Université Blaise Pascal, called 'Production de Documentation Normalisée' (see Table 1). While the former program has shown itself to be successful in many respects, the new Masters program, called 'Langues et Communication Technique" (MLCT), intends to broaden its recruitment base by strongly reinforcing instruction in written communication, intercultural communication, foreign languages, and the business environment.

Based on the preceding discussion about the French university context, the following specific needs have been identified for technical communication education in France and, as a result, for MLCT's curriculum:

- providing vast practice in writing different genres for different audiences;

- developing rhetorical awareness in using different genres (audience, situation, purpose, genre, style);

- developing skills in user-centered communication;

- developing a professional identity through writing;

- developing and reinforcing an understanding of genres as dynamic discoursal forms;

- continuing to develop an advanced awareness of intercultural differences, practices and communication;

- combining specialized discoursal knowledge with IT tools;

- grounding discoursal and technical knowledge within the business environment.

Such curricular needs are intended to promote the growth of intercultural technical communication education in France by both continuing to build on students' existing intercultural awareness and competence in foreign languages and by providing intensive training in the various aspects of written communication (roughly 240 hours), IT tools and the business environment.

The Masters program is designed to train students to work as specialists in intercultural technical communication, by giving them expertise in company operations, knowledge management, IT tools, specialized foreign languages and international business. These objectives are covered over a two-year program, with approximately 400 annual teaching hours for each year of the Masters. Each year focuses on specific aspects of technical communication and allows students to apply their coursework during two 
specialized work placements in a French or international company.

\section{Year 1}

Introduction to technical communication

Intercultural skills

Workplace communication

English

Applied translation

Communication technologies

Business environment

Professional practice

\section{Year 2}

Advanced technical communication

Languages \& Communication

Communication theories

Business environment

Communication technologies

Professional practice
Procedural writing (descriptions, instructions, procedures, warnings), task analysis, user-centered texts, industry standards

Intercultural business and technical communication

Report and proposal writing

Oral expression, English-French translation

German, Arabic, Chinese, Spanish, Italian, Portuguese, or Russian

HTML programming

Website design

Project management

Fundamentals of management

Marketing

European Law

Information systems

Supervised work placement in international or French company (16 weeks minimum)

Online procedural writing, benefits writing, web designand web publishing, online help, training simulation videos

Controlled Languages

Applied translation

Visual communication \& visual design

Oral communication

Accessibility and human factors

User-based design

Usability studies and user interview techniques

Promotional language and advertising

International project management

Company knowledge management

Company strategies

Quality assurance

Localization

Collaborative authoring tools

Metadata and database management (Structured XML, Content Mapping,

Content Management Systems)

Computer-assisted translation

Translation Management Systems

Desktop publication software

Supervised work placement in international or French company (20 weeks minimum)

Design project

Redesigning an L.E.A. program's traditional emphasis on translation to have it focus more closely on 
writing, while retaining its emphasis on intercultural differences and the business environment, is an interesting move for at least three reasons:

1. Being housed in a business-oriented faculty allows French students to continue acquiring the essentials of the business environment. Students trained as business-savvy communicators, involved with process design and usability testing, trained in the latest IT trends, will be valuable assets to companies, allowing companies to save both time and money;

2. A heavy emphasis on writing instruction, notably through a rhetorical and action-based approach to technical communication, will allow French students to refine and develop their 'dormant' writing skills;

3. The reinforcement of writing instruction will allow for students to become accomplished technical writers, in addition to being translators. This choice reflects recent trends on the job market in France where calls are increasingly made for technical writers capable of producing a variety of technical and professional documents.

\section{Working with French technical communicators}

As a new generation of technical communicators are trained in France, they will increasingly come into contact with North American technical communicators. In order to work and interact with them more effectively, a number of intercultural considerations must be taken into account. The technical communication professionals working in France and Europe who were interviewed for this chapter point overwhelmingly to similar considerations. First, the basics of the technical communicator's job are the same, irrespective of country or language. To effectively work in an intercultural environment, it is important to know how to look, listen and behave in different environments.

These skills can be taken a basis for the following behaviors which are crucial to working more effectively in and with France's intercultural business environment.

(1) Be polyvalent - Be willing to multitask:

Writers in France and Europe often find themselves doing a great deal of multitasking in their day-today work. Due to the globalized environment in which their companies typically operate and the accompanying localization concerns, French technical writers are often involved in document/quality control and budgets, in addition to writing technical documents.

(2) Be aware of localization needs:

Due to the geopolitical and cross-linguistic contexts in which they work, technical writers in France and Europe must also constantly adapt their communication and styles to various local markets. In this sense, it is important to identify what is, for example, specific to North American markets, what is international, and what is specific to other regional markets. Such 'local' differences go beyond metric or imperial measurements and paper size. They include:

- Worldview: one of the biggest problems cited by technical communicators in working with some US writers or editors is that it is often assumed that what is done in the US operates in the same way in the rest of the world. Customers from France do not necessarily want the same things as North American customers.

- ISO standards: Europe overwhelmingly uses ISO standards; French and European writers still encounter difficulty in having EU directives (i.e., European law) implemented in documents produced in the United States.

- Legal issues: Legal issues tend to be different in France and the United States.

- Language issues: The problem of language goes well beyond obvious translation problems by also including how one distributes multiple language versions of documents in a global market. This becomes difficult because, for example, the process of document distribution 
differs from one language to another.

(3) Learn to speak the local language:

Overwhelmingly, all the technical communication professionals consulted during the survey stress the same point: to work more easily with French technical communicators, developers and engineers, it is crucial to learn how to speak French. As a general rule, people tend to cooperate better when things have been made as easy as possible for them, here by speaking French.

- When the French see you are making an effort at communicating with them in their own language, they become more open and willing to cooperate. It is a well-appreciated courtesy, even if your French is basic.

- Not only is it polite, it often easier to obtain information from French speakers in French. To be more effective, interviews and investigations should be conducted in French.

- Even if the French speakers who work in technical communication in France often speak good, if not excellent, English, most still prefer to communicate in French.

(4) Maintain a respectful attitude:

When North-American technical communicators are dealing with their French colleagues, another extremely important consideration to keep in mind is to remember to treat them as equals.

- Be patient and allow for extra time. If there are questions about the services or products being documented, it may not be possible for the French technical writer to answer them immediately. If the technical writer needs to go back and interview the source, it may take some time. In France, carrying out a task that relies on the input of several people tends to take longer than in the US.

- Avoid assuming that because someone has English as a second language that their written English will be poor. Many French technical writers do appreciate having their written English edited, but only when it is done so respectfully.

(5) Be aware of behavioral differences:

It is also important to observe French colleagues to see what forms of behavior are acceptable for different situations.

- Personal space in France, as well as in other parts of Europe, is smaller than it is in the US. People tend to stand closer together, such as when they are waiting in line (making them appear 'pushy') or when talking to one another.

- People in France also tend to touch one another more. There is more kissing and hand-shaking as a greeting, especially the first time colleagues see one another in the morning.

\section{Conclusion}

Today, technical communication is still a 'new' field in France. Apart from the programs in technical communication offered at the Université de Paris 7 and Université Blaise Pascal, however, training for French technical writers is still largely translation-based. Nonetheless, there is now a strongly recognized need among French companies for well-trained technical communicators, able to cope not only with the usual translation tasks, but also with user-based communication tasks, accessibility, usability studies, localization, local and international project management, knowledge management, and IT technology. According to one Paris-based business, which develops and supplies open-source software to the largest French companies and administrations, the current need for trained technical communicators in France is such that without them, French companies will soon be forced to import technical communicators from other countries. To meet this urgent need, French universities must quickly adapt by offering communication-rich programs in technical communication, rather than translation-training only, in order 
to provide the wide range of skills needed in the profession today.

Clearly, this is a time of opportunity and change, crucial for the promotion and development of technical communication in France. In the coming years, ongoing cooperation between various university programs, namely between Rennes 2, Paris 7 and Blaise Pascal universities, can only reinforce and vitalize the training and professionalization of students in technical communication in France.

\section{References}

Adam, J.M. (1992). Les textes: types et prototypes. Paris: Nathan.

Altet, M. (1997). Les pédagogies de l'apprentissage. Paris: P.U.F.

Astolfi, J.P. (1993). L'école pour apprendre. Paris: E.S.F.

Bautier, E. (1995). Pratiques langagières, pratiques sociales: de la sociolinguistique à la sociologie du langage. Paris: L'Harmattan.

Beaufort, A. (1999). Writing in the real world: making the transition from school to work. New York: Teachers College Press.

Burgel, G. 2006. The university, a French dilemma. Paris: Hachette [in French].

Charlot, B., Bautier, E. and J.Y. Rochex. (1992). Ecole et savoir dans les banlieues et ailleurs. Paris: A. Colin.

Donahue, C. (1996). "French students' writing ability as a method of transcending the boundary into post-secondary studies." Paper presented at the Conference on College Composition and Communication, Milwaukee, Wisconsin, 1996.

Donahue, C. (2000). Genres, textual movement and subjectivity in learning academic writing: Interpreting the discourse of French and American student writers. Unpublished PhD Dissertation, University of Paris 5 [in French].

Donahue, C. (2004). "Writing and teaching the disciplines in France: Current conversations and connections." Arts and Humanities in Higher Education, 3: 59-79.

Dressen-Hammouda, D. (2004). "Directed communicative modeling: Contributions of the genre approach to teaching professional English" [in French]. Les Cahiers de l'APLIUT, 23: 89-102.

Dressen-Hammouda, D. (2006). "A challenge for teaching LSP: Mitigating text and the need for multimodality" [in French]. Les Cahiers de l'APLIUT, 25: 60-73.

Dressen-Hammouda, D. (To appear). "Aligning EAP writing pedagogies across European universities: a case study from France”, In I. Fortanet-Gómez and C. Räisänen (Eds.), Toward a Harmonized European Higher Education: English as the Medium of Teaching and Learning. Amsterdam: John Benjamins, AILA Applied Linguistics Series.

ELAN (December 2006). Effects on the European Economy of Shortages of Foreign Language Skills in Enterprise [electronic version]. Retrieved 16 June, 2007 from HYPERLINK "http://www.cilt.org.uk/key/elan_finalreport.pdf" www.cilt.org.uk/key/elan_finalreport.pdf.

Fayol, M. (1995). "Des modèles de production du langage à l'étude du fonctionnement du scripteur enfant et adulte", In J.Y. Boyer, J.P. Bionne \& P. Raymond (Eds.), La production de textes, vers un modèle d'enseignement/apprentissage de l'écriture. Montréal: Logiques.

Fayol, M. (1996). “Apprendre à produire des textes”, In C. Barré de Miniac (Ed.), Vers une didactique de l'écriture. De Boeck et Larcier et I.N.R.P.

Fayol, M. (1999). "L'apprentissage de la lecture et de l'écriture”, In J.A. Rondal \& E. Esperet (Eds.), Manuel de psychologie de l'enfant. Bruxelles: Mardaga.

Fayol, M. (2004). "Les difficultés de l'orthographe". Cerveau \& Psycho, 3: 2-5.

Gallet-Blanchard, L. and Peyronel, V. (2006). "La place de la recherche et de la reconnaissance institutionnelle en LEA/LANSAD." Paper presented at Journées d'études sur le thème LEA/LANSAD : Convergences/ Divergences. Nantes (France), 13-14 January 2006.

Garcia-Debanc, C. (1993). "Peut-on programmer les apprentissages en production d'écrits?” In A. Bentolila (Ed.), Les entretiens Nathan actes III, Paroles, écrit, image. Paris: Nathan.

Haas, G. and D. Lorrot. (1987). "Pédagogie de texte descriptif”. Pratiques, 55.

Lahire, B. (1993). Cultures écrites et inégalités scolaires. Lyon: P.U.L.

Miller, C. (1984). Genre as social action. Quarterly Journal of Speech, 70: 151-67. Second publication in A. Freedman \& P. Medway (Eds.). (1994). Genre and the new rhetoric. Bristol, PA: Taylor \& Francis.

Piolat, A. (2004). (Ed.). Ecriture. Approches en sciences cognitives. Aix-en-Provence : Presses Universitaires de Provence.

Piolat, A. and Pélissier, A. (1998). (Eds.). La rédaction de textes. Approche cognitive. Lausanne : Delachaux \& 
Niestlé.

Plane, S. (2003). “L'écriture et son apprentissage à l'école primaire”. Repères: 26-27.

Reuter, Y. (1996). Enseigner et apprendre à écrire. Paris: E.S.F.

Thin, D. (1998). Quartiers populaires: l'école et les familles. Lyon: P.U.L.

\section{Notes:}

$1 \quad$ Also described in Dressen-Hammouda (2006).

2 Such school genres include synthesis essays based on historical or geographical documents, philosophical essays in response to general philosophical essays, or French essays that draw on primary sources and develop themes of analysis: dissertation, commentaire composé, etc. (see also Donahue, 2004, p. 65).

3 A special issue of the group's journal, ASp: la revue $d u$ GERAS, was specifically dedicated to the problem of 'rédaction', or writing research and instruction in France. The researchers who have contributed to this important bed of research have coined the term 'rédactologie' in response to the well-established French tradition of the study of translation ('traductologie'). See ASp, 37-38 (2002), and notably articles written by S. Birch-Bécass, C. Sionis, K. Nakbi, and R. Cooke, which can be ordered from www.geras.fr/dossiers/dossiers.php?val=24_n\%B037+38

4 This comment is based on my own observations as a writing instructor in English. In effect, in the six years I have taught a 3rd-year writing-intensive Business English course in our L.E.A. Bachelors program at Université Blaise Pascal (Clermont 2), I have observed that while in theory, our students have had prior experience - in French - writing various professional genres during their first two years ('techniques d'expression'), this experience proves to be ineffective because in the writing-intensive Business English courses, most of them have sizeable difficulty in adequately adapting their genres to the different rhetorical situations they encounter in task-based scenarios (Dressen-Hammouda, 2004; 2006; to appear). Their difficulty in carrying out such tasks in English belies their inexperience in writing audience-centered texts in their first language. Moreover, although it is always somewhat tenuous to make generalizations based on limited personal observations, I do not believe it unreasonable to expect that the situation is any different for students coming out of other L.E.A./technical writing programs in France, given that even less writing instruction is usually provided at most other institutions (Table 1).

5 The report, entitled 'Effects on the European Economy of Shortages of Foreign Language Skills in Enterprise', was prepared by the UK National Centre for Languages (CILT), in collaboration with InterAct International and an international team of researchers. Its objective was to provide the Commission and decision-makers in European Member States with practical information and analysis of the use of language skills by SMEs and the impact on business performance.

6 http://www.bologna-berlin2003.de/pdf/bologna_declaration.pdf

7 For more information, see HYPERLINK "http://www.prelude.in2p3.fr" www.prelude.in2p3.fr. This program is further discussed by Donahue (2004). 